\title{
Identification of Climate Resilient Sesame (Sesamum indicum L.) Genotypes Suitable for Southern Region of A. P, India
}

\author{
N. Sabitha* \\ Regional Agricultural Research Station, Tirupathi, India \\ *Corresponding author
}

\section{A B S T R A C T}

\section{Keywords \\ Sesame, \\ Multilocation trial, Seed yield components}

\section{Article Info}

Accepted:

15 July 2020 Available Online: 10 August 2020
A study involving eight sesame genotypes conducted during 2018-2019 at the Regional Agricultural Research Station, Tirupathi with an objective of identifying climate resilient Sesame genotypes suitable for both Kharif and rabi seasons in southern region of Andhra Pradesh indicated the existence of differential response of genotypes for seed yield and yield components except for number of branches pert plant in both the seasons. Combined analysis also revealed that the genotypes differed significantly for all the characters except for branches per plant. The component of variation due to seasons was significant for all the characters except for days to maturity and thousand seed weight. The genotype $\mathrm{x}$ seasons interaction was non significant for number of branches per plant indicating the less influence of environment on the expression of the character. Among the sesame genotypes studied YLM 136 was found to be early in flowering and maturity. Plant height was more in rabi season compared to Kharif. Similar trend was recorded for number of capsules per plant. The genotypes viz., YLM 136 and YLM 139 have recorded more number of capsules per plant in both the seasons. All the genotypes recorded higher mean values for Specific Chlorophyll meter readings over the check YLM 66 in both the seasons. Hundred seed weight was found higher in rabi season compared to Kharif. Three genotypes viz., YLM 136, YLM 142 AND YLM 147 have registered higher mean values for seed weight over the seasons. Mean seed yield was found to be higher in rabi over Kharif season. All the genotypes have recorded higher seed yield over the check YLM 66 in Kharif while YLM 136, YLM 142, YLM 146 and YLM 147 registered higher seed yield during rabi over YLM66. Based on seed yield and yield components and two seasons YLM 136 and YLM 142 were found to be superior to the check YLM 66 for seed yield. Theses genotypes may be recommended for commercial cultivation in Southern region of Andhra Pradesh after extensive testing under on - farm testing / adaptive minikit testing.

\section{Introduction}

Sesame (Sesamum indicum L.) is one of the important oilseed crops after groundnut. Its oil contains an oxidant called Sesmol which imparts longer shelf life. Sesame is also rich in phosphorous, iron, magnesium, manganese, zinc, and vitamin B1 (Anilakumar et al., 2010). It is grown primarily in west Godavari, Srikakulam, Vizianagaram, Visakhapatnam, Prakasam, Kadapa and Chittoor districts of A.P. (Directorate of Economics \& Statistics, 
Govt. of A.P., 2018). It is cultivated in all the three seasons viz; Kharif, Rabi and Summer seasons but mostly in Kharif season as rainfed crop and in rabi and summer it is raised under irrigated conditions. However, sesame crop yields are low $(269 \mathrm{~kg} / \mathrm{ha})$ in the state compared to the national average yields. Moisture stress, Phyllody, Alternaria leafspots, non-availability of improved varieties with high seed yield, oil content and non pod shattering nature are the major constraints in sesame cultivation in the state. The present investigation involving advanced sesame genotypes of Sesame was carried out to identify location specific high yielding genotypes with desirable agronomic and economic characters suitable for the light soils of Southern region of Andhra Pradesh.

\section{Materials and Methods}

Multilocation trial with eight sesame genotypes including one check (YLM 66) was conducted at Regional Agricultural Research Station, Tirupati during Kharif \& rabi, 20182019 seasons The experiment was laid out in a Randomized block design with three replications. Experiment each genotype was raised in ten rows of four meter length adopting 30x10cm spacing. Recommended dose of fertilizers @ 40:20:20 kg NPK/ha was applied as basal at the time of sowing. Cultural practices and crop protection measures were adopted as per the recommendations of ZREAC for the Southern Zone of A.P. Data were collected on days to $50 \%$ flowering (DF), days to maturity (DM), plant height $(\mathrm{PH})$, No. of branches/plant (BPP), no. of capsules/plant(CPP) and Thousand seed weight(g) as (TSW) and seed yield ( $\mathrm{kg} / \mathrm{ha})$ during crop growth and at harvest analysis of variance was carried out as per the standard statistical procedures using the OPSTAT software (O.P Sheoran). To establish the magnitude of the variation among cultivars, comparison of means was made with at five per cent level of significance (Panse and Sukhatme, 1978).

\section{Results and Discussion}

Analysis of variance for seed yield and yield components in Kharif and rabi seasons revealed the existence of variation among the genotypes for days to 50 per cent flowering, days to maturity, plant height, number of capsules per plant, SPAD meter readings, thousand seed weight and seed yield except for number of branches per plant during Kharif, 2018. Mean sum of squares were significant among the genotypes for days to maturity, plant height, number of capsules per plant, SPAD meter readings, thousand seed weight and seed yield except for days to $50 \%$ flowering and number of branches per plant during rabi. Combined analysis also revealed that the genotypes differed significantly for all the characters except for branches per plant. Similar results were also reported by Bharathi et al., (2014) and Baraki et al., (2016).

The component of variation due to seasons was significant for all the characters except for days to maturity and hundred seed weight. The genotype $\mathrm{x}$ seasons interaction was non significant for number of branches per plant indicating the less influence of environment on the expression of the character (Table 1).

Performance of the sesame genotypes for seed yield and yield contributing characters is furnished in Table 2. Among the genotypes YLM 136 was found to be early in flowering (35days)and maturity (78days) compared to the check YLM 66 (44 and 86 days) in Kharif while YLM 146 was noted for early flowering (42 and 75.30 days) and maturity in rabi season. Plant height was found to be low in among the sesame genotypes during Kharif, 2018(76.7cm) compared to rabi 2018-19 (109 $\mathrm{cm})$. 
Table.1 Combined analysis for seed yield and yield contributing characters of sesame (2018-2019)

\begin{tabular}{|l|c|c|c|c|c|c|c|c|c|}
\hline Source of Variation & $\mathbf{d f}$ & $\mathbf{D F}$ & $\mathbf{D M}$ & $\mathbf{P H}(\mathbf{c m})$ & $\mathbf{B P P}$ & $\mathbf{C P P}$ & SPAD & TW(g) & Seed yield(kg/ha) \\
\hline Replications & 1 & 3.083 & 4.95 & 5.92 & 0.667 & 2.23 & 1.41 & 0.07 & 6.17 \\
\hline Genotypes & 7 & $9.89 * *$ & $56.94 * *$ & $42.84 * *$ & 1.164 & $239 * *$ & $143.558^{* *}$ & $0.39 * *$ & $44833.45 * *$ \\
\hline Seasons & 1 & $130.02 *$ & 1.33 & $12393.8 * *$ & $25.521 * *$ & $15624.1 * *$ & $324.91 * *$ & 0.02 & $147232.13 * *$ \\
\hline Seasons x Genotypes & 7 & $14.4 * *$ & $26.57 * *$ & $32.81 * *$ & 0.62 & $45.32 * *$ & $33.05 * *$ & $0.06 * *$ & $18521.61 * *$ \\
\hline Pooled Error & 28 & 1.2 & 4.64 & 4.48 & 0.524 & 2.71 & 0.95 & 0.01 & 4.41 \\
\hline
\end{tabular}

*Significant at 5 per cent level of probability

** Significant at 1 per cent level of probability

Table.2 Performance of sesame genotypes for seed yield and yield components in Kharif and rabi seasons (2018-2019)

\begin{tabular}{|c|c|c|c|c|c|c|c|c|c|c|c|c|}
\hline \multirow[t]{2}{*}{$\begin{array}{c}\text { Genotype/ } \\
\text { season }\end{array}$} & \multicolumn{3}{|c|}{ DF } & \multicolumn{3}{|c|}{ DM } & \multicolumn{3}{|c|}{ Plant height(cm) } & \multicolumn{3}{|c|}{$\begin{array}{c}\text { No. of Branches/ } \\
\text { plant (BPP) }\end{array}$} \\
\hline & Kharif & Rabi & Mean & Kharif & Rabi & Mean & Kharif & $R a b i$ & Mean & Kharif & Rabi & Mean \\
\hline YLM 136 & 35 & 42 & 39 & 78 & 82 & 80 & 77 & 101.3 & 89.2 & 3 & 5 & 4 \\
\hline YLM 139 & 37 & 43 & 40 & 84 & 77 & 81 & 78.1 & 114.3 & 96.2 & 4 & 5 & 4 \\
\hline YLM 141 & 38 & 42 & 40 & 78 & 85 & 82 & 77.7 & 110.2 & 94.0 & 4 & 6 & 5 \\
\hline YLM 142 & 39 & 41 & 40 & 81 & 81.3 & 81 & 77.3 & 114.7 & 96.0 & 4 & 5 & 4 \\
\hline YLM 143 & 41 & 43 & 42 & 86 & 86 & 86 & 76.3 & 111.7 & 94.0 & 3 & 5 & 4 \\
\hline YLM 146 & 40 & 42 & 41 & 80 & 75.3 & 78 & 73.9 & 109.3 & 91.6 & 3 & 4 & 4 \\
\hline YLM 147 & 38 & 42 & 40 & 83 & 83.3 & 83 & 74.6 & 103.7 & 89.1 & 3 & 5 & 4 \\
\hline YLM 66 & 44 & 41 & 43 & 86 & 86 & 86 & 78.5 & 106.7 & 92.6 & 3 & 5 & 4 \\
\hline GM & 39 & 42 & 41 & 82 & 82 & 82 & 76.7 & 109.0 & 92.8 & 3 & 5 & 4 \\
\hline $\mathrm{CD}$ & 1.81 & NS & NS & 1.12 & 5.31 & 0.98 & 2.15 & 3.96 & 2.89 & NS & NS & NS \\
\hline $\mathrm{CV} \%$ & 2.63 & 3.2 & 1.89 & 0.77 & 3.66 & 2.10 & 4.95 & 7.67 & 4.10 & 2.52 & 3.60 & 2.95 \\
\hline
\end{tabular}


Contd...Table.2

\begin{tabular}{|c|c|c|c|c|c|c|c|c|c|c|c|c|}
\hline \multirow[t]{2}{*}{$\begin{array}{l}\text { Genotype / } \\
\text { season }\end{array}$} & \multicolumn{3}{|c|}{$\begin{array}{c}\text { No. of Capsules/plant } \\
(\text { CPP })\end{array}$} & \multicolumn{3}{|c|}{$S P A D$} & \multicolumn{3}{|c|}{ Test weight (g) } & \multicolumn{3}{|c|}{ Seed yield (kg/ha) } \\
\hline & Kharif & Rabi & Mean & Kharif & Rabi & Mean & Kharif & Rabi & Mean & Kharif & Rabi & Mean \\
\hline YLM 136 & 62 & 89 & 76 & 62.8 & 47.8 & 55.3 & 2.8 & 3.0 & 2.9 & 631 & 647.8 & 639.4 \\
\hline YLM 139 & 53 & 92 & 73 & 66.2 & 60.8 & 63.5 & 2.4 & 2.5 & 2.5 & 499.8 & 617.8 & 558.8 \\
\hline YLM 141 & 53 & 85 & 69 & 60.4 & 54.6 & 57.5 & 2.3 & 2.4 & 2.4 & 462.3 & 581.8 & 522.1 \\
\hline YLM 142 & 54 & 84 & 69 & 64.4 & 60.6 & 62.5 & 2.9 & 2.7 & 2.8 & 780.9 & 713.2 & 747.1 \\
\hline YLM 143 & 46 & 87 & 67 & 54.6 & 52.4 & 53.5 & 2.2 & 2.3 & 2.3 & 393.6 & 623.2 & 508.4 \\
\hline YLM 146 & 35 & 76 & 56 & 54.2 & 55.7 & 55.0 & 2.4 & 2.2 & 2.3 & 562.3 & 666.8 & 614.6 \\
\hline YLM 147 & 45 & 80 & 62 & 57.2 & 50.6 & 53.9 & 3.0 & 2.7 & 2.9 & 568.5 & 648.3 & 608.4 \\
\hline YLM 66 & 42 & 85 & 64 & 50.7 & 46.5 & 48.6 & 2.5 & 2.3 & 2.4 & 337.4 & 622.2 & 479.8 \\
\hline GM & 49 & 85 & 67 & 58.8 & 53.6 & 56.2 & 2.6 & 2.8 & 2.7 & 529.5 & 640.1 & 584.8 \\
\hline $\mathrm{CD}$ & 3.53 & 4.16 & 3.96 & 2.2 & 2.08 & 3.20 & 0.17 & 0.16 & 0.19 & 87.06 & 19.47 & 30.20 \\
\hline $\mathrm{CV} \%$ & 6.41 & 10.46 & 9.20 & 4.3 & 4.7 & 5.10 & 5.4 & 5.2 & 4.80 & 9.20 & 6.56 & 8.57 \\
\hline
\end{tabular}

However the differences among the genotypes for plant height were significant in both the seasons. Among the genotypes YLM 139 (78.10 and $114.3 \mathrm{~cm})$ and YLM 142 (77.3 and $1147 \mathrm{~cm}$ ) recorded higher plant height in both the seasons. Less variation was noted among the genotypes for number of branches per plant in both the seasons but number of branches per plant were more in rabi (5) compared to Kharif (3). The genotype YLM 141 registered more branches per plant in both the seasons. Similar trend was recorded for number of capsules per plant during Kharif and rabi. Seasonal variation of seed yields were recorded by Ahmed and Ahmed (2010). More number of capsules per plant were noted in rabi (85) over Kharif (49). The genotypes viz; YLM 136 and YLM 139 were found significantly superior to the check YLM 66 for capsules per plant over the seasons while YLM 141 and YLM 142 in Kharif and YLM 143in rabi recorded more number of capsules per plant.

Specific chlorophyll meter readings among the genotypes were found to be high during Kharif (58.80) compared to rabi (53.6) seasons. All the sesame genotypes have recorded higher SPAD values over the check YLM 66 in both the seasons. Among the genotypes YLM 139 (63.5) and YLM 142 (62.5) registered significantly higher values for SPAD meter reading over seasons compared to YLM 66 (48.6). Mean thousand seed weight was found high in rabi $(2.8 \mathrm{~g})$ compared to Kharif (2.6 gm) season. However, the genotypic variation was noted for seed weight in both the seasons. YLM 136, YLM 142 and YLM 147 registered significantly higher seed weight over the check YLM 66 and over two seasons. Hundred seed weight was found higher in rabi season compared to Kharif.

The genotypes differed significantly for seed yield in Kharif and rabi seasons. However, mean seed yield was found to be higher in rabi $(640.10 \mathrm{~kg} / \mathrm{ha})$ over Kharif $(529.50 \mathrm{~kg}$ /ha). Wide variation for seed yield in sesame was also reported by Chandra Mohan (2011). All the genotypes have recorded higher seed yield over the check YLM $66(337.4 \mathrm{~kg} / \mathrm{ha})$ in Kharif while YLM 136, YLM 142, YLM 146 and YLM 147 registered higher seed yield during rabi over YLM66 (622.2 kg/ha) . Among the genotypes YLM 142 
(747.10kg/ha), YLM $136 \quad(639.40 \mathrm{~kg} / \mathrm{ha})$, YLM 146 (614.60kg /ha) and YLM 147 $(608.4 \mathrm{~kg} / \mathrm{ha})$ recoded significantly higher seed yield compared to the check YLM 66 $(479.8 \mathrm{~kg} / \mathrm{ha})$ over two seasons.

In conclusions based on the performance of the sesame genotypes over two seasons for seed yield and yield contributing characters it is concluded that YLM 136 and YLM 142 may be recommended for commercial cultivation after thorough testing under onfarm trials and adaptive minikit testing.

\section{References}

Agricultural Statistics at a Glance - Andhra Pradesh. 2018. Publication by Directorate of Economics \& Statistics, Govt. of Andhra Pradesh. pp: 25-26

Ahmed, M. B. S. and F. A. Ahmed,2010. "Genotype $\times$ season interaction and characters association of some Sesame (Sesamum indicum L.) genotypes under rain-fed conditions of Sudan," African Journal of Plant Science, vol. 6, no. 1, pp. 39-42, 2012.

Anilakumar R. K., A. Pal, F. Khanum and A. S. Bawa, 2010. Nutritional, medicinal and industrial uses of sesame (Sesamum indicum L.) seeds, Agriculturae Conspectus Scientificus, vol. 75(4

Baraki, F. Y. Tsehaye, and F. Abay, 2016. Analysis of genotype $\times$ environment interaction and seed yield stability of sesame in Northern Ethiopia. Journal of Plant Breeding and Crop Science, vol. 8, no. 11, pp. 240-249, 2016.

Bharathi, D; Thirumalaao, V; Chandramohan, Y; Bhadru, D and Venkanna. V. 2014. Genetic variability studies in Sesame (Sesamum indicum L). International Journal of Applied Biology and Pharmaceutical Technology. (4): 3133.

Chandra Mohan, Y. 2011. Genetic variability, Genetic advance and character association in Sesame (Sesamum indicum L.). Crop Research. 42(10): 259-262.

Panse, V.G. and Sukhatme 1978. Statistical methods for Agricultural Workers. ICAR, New Delhi Publication.

Sheoran, O.P Hisar statistical package for Agricultural scientists (OPSTAT), CCSHAU.http://www.202.141.47.5/op stat/index.asp.

\section{How to cite this article:}

Sabitha, N. 2020. Identification of Climate Resilient Sesame (Sesamum indicum L.) Genotypes Suitable for Southern Region of A. P, India. Int.J.Curr.Microbiol.App.Sci. 9(08): 1497-1501. doi: https://doi.org/10.20546/ijcmas.2020.908.173 